\title{
USE OF THE BIBLIOGRAPHIC REFERENCE MANAGER IN THE SELECTION OF PRIMARY STUDIES IN INTEGRATIVE REVIEWS
}

\author{
Karina Dal Sasso Mendes ${ }^{1}$ (D) \\ Renata Cristina de Campos Pereira Silveira ${ }^{1}$ (i) \\ Cristina Maria Galvão ${ }^{1}$ (1)
}

${ }^{1}$ Universidade de São Paulo, Escola de Enfermagem de Ribeirão Preto, Departamento de Enfermagem Geral e Especializada, Ribeirão Preto, SP, Brasil.

\begin{abstract}
Objective: present the use of the bibliographic reference manager EndNote ${ }^{\circledR}$ as a support tool in the construction of a database and the selection of primary studies to develop integrative reviews. Method: a reflection study was undertaken, based on the international and the Brazilian literature. Results: the elaboration of an integrative review permits summarizing the knowledge about the theme of interest delimited in the health area, which can contribute by providing recommendations based on research results for clinical practice, as well as by identifying knowledge gaps, driving future research development. The use of bibliographic reference management tools is important for the selection of primary studies, permitting the location of repeated references, identification of languages, selection of publication periods and the creation of citations in the elaboration of the scientific text, among other resources.

Conclusion: the advance in technologies, particularly the software EndNote ${ }^{\circledR}$, has provided resources for the practicability of knowledge synthesis methods, in a transparent and replicable manner, consequently entailing a better quality of this type of study.
\end{abstract}

DESCRIPTORS: Research. Nursing. Review literature as topic. Bibliography. Information Management. Software. Methods. 


\section{USO DE GERENCIADOR DE REFERÊNCIAS BIBLIOGRÁFICAS NA SELEÇÃO DOS ESTUDOS PRIMÁRIOS EM REVISÃO INTEGRATIVA}

\section{RESUMO}

Objetivo: apresentar o uso do gerenciador de referências bibliográficas EndNote ${ }^{\circledR}$ como ferramenta para auxiliar na construção de banco de dados e seleção de estudos primários na condução de revisão integrativa.

Método: trata-se de um estudo de reflexão, pautado na literatura internacional e nacional.

Resultados: a elaboração de revisão integrativa possibilita a síntese de conhecimento sobre o tópico de interesse delimitado na área da saúde, a qual pode contribuir com recomendações pautadas em resultados de pesquisas para a prática clínica, bem como na identificação de lacunas do conhecimento direcionando o desenvolvimento de pesquisas futuras. $O$ uso de ferramentas para o gerenciamento de referências bibliográficas é importante para operacionalizar a seleção dos estudos primários, possibilitando a localização de referências duplicadas, identificação de idiomas, seleção de períodos de publicação, criação de citações na construção do texto científico, entre outros recursos.

Conclusão: o avanço das tecnologias, em especial o programa EndNote ${ }^{\circledR}$, tem proporcionado recursos para a exequibilidade de métodos de síntese de conhecimento, com transparência e reprodutibilidade e, consequentemente acarretando a melhoria da qualidade deste tipo de estudo.

DESCRITORES: Pesquisa. Enfermagem. Literatura de revisão como assunto. Bibliografia. Gestão da Informação. Software. Métodos.

\section{USO DE GERENCIADOR DE REFERENCIAS BIBLIOGRÁFICAS EN LA SELECCIÓN DE LOS ESTUDIOS PRIMARIOS EN REVISIÓN INTEGRATIVA}

\section{RESUMEN}

Objetivo: presentar el uso del gestor de referencias bibliográficas EndNote ${ }^{\circledR}$ como herramienta para auxiliar en la construcción de base de datos y selección de estudios primarios en la conducción de revisión integrativa.

Método: se trata de un estudio de reflexión, pautado en la literatura internacional y nacional.

Resultados: la elaboración de revisión integrativa posibilita la síntesis de conocimiento sobre el tema de interés delimitado en el área de la salud, la cual puede contribuir con recomendaciones pautadas en resultados de investigaciones para la práctica clínica, así como en la identificación de lagunas del conocimiento dirigiendo el desarrollo de investigaciones futuras. El uso de herramientas para la gestión de referencias bibliográficas es importante para operacionalizar la selección de los estudios primarios, posibilitando la localización de referencias duplicadas, identificación de idiomas, selección de períodos de publicación, creación de citas en la construcción del texto científico, entre otros recursos.

Conclusión: el avance de las tecnologías, en especial el programa EndNote ${ }^{\circledR}$, ha proporcionado recursos para la viabilidad de métodos de síntesis de conocimiento, con transparencia y reproducibilidad y, consecuentemente, acarreando la mejora de la calidad de este tipo de estudio.

DESCRIPTORES: Investigación. Enfermería. Literatura de revisión como asunto. Bibliografía. Gestión de la información. Software. Métodos. 


\section{INTRODUCTION}

The synthesis of knowledge is the scientific method for summarizing evidence from various studies on a specific theme, identifying gaps in research and suggesting new studies, as well as for providing the best evidence available for making decisions in health. The knowledge synthesis methods include the systematic review, meta-analysis, qualitative synthesis, and integrative review. Currently, new methods are being proposed, such as mixed study review, scope review and umbrella review (reviews of systematic reviews). ${ }^{1-2}$

The quantity and complexity of new knowledge production in the health area, added to the professionals' time constraints, has led to an increase in the development of knowledge synthesis methods among health researchers, especially in nursing. ${ }^{3}$

The integrative review (IR) is a method that permits summarizing knowledge through a systematic and rigorous process. The development of the IR needs to be based on the same principles of methodological rigor in the development of research. The steps of this method are: 1) elaboration of the review question; 2) search and selection of primary studies; 3 ) data extraction from the studies; 4 ) critical evaluation of the primary studies included in the review; 5) synthesis of the review results and 6) presentation of the method (figure 1). ${ }^{2,4-5}$

Figure 1 - Steps of the integrative review, Ribeirão Preto, São Paulo, 2017²,4-5

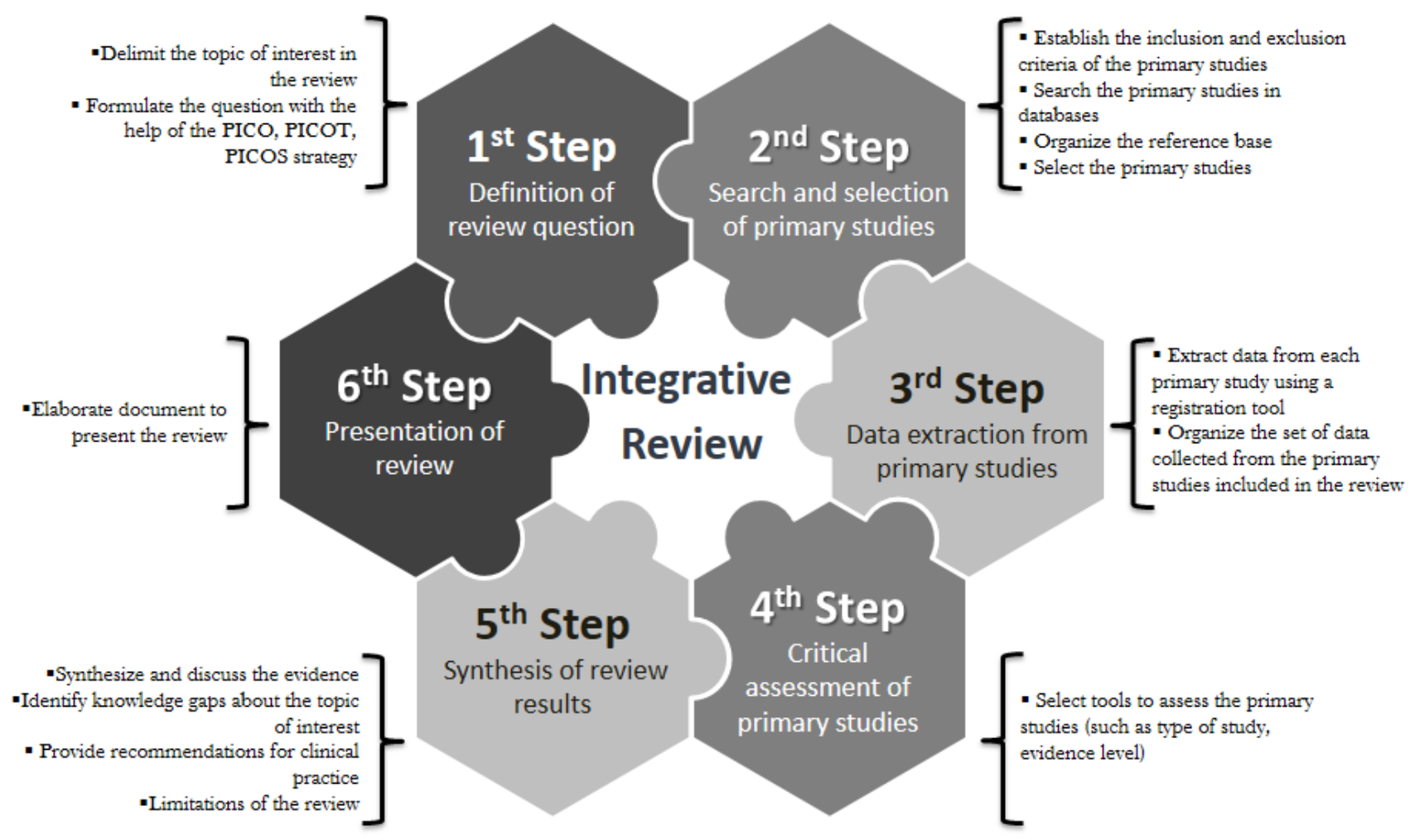

The importance of methodological rigor in IR and the need to use tools to manage the selection of primary studies were the aspects considered to construct this reflection for health researchers. Thus, in view of the authors' experience in the practice of review methods using the reference manager, in addition to the productions in Brazilian nursing that used IR as a method, the objective of this reflection is to present the use of the $\mathrm{EndNote}^{\circledR}$ bibliographic reference manager as a support tool in the construction of a database and in the selection of primary studies for integrative reviews. 


\section{REVIEW QUESTION AND PRIMARY STUDY SEARCH STRATEGY}

The researcher should delimit the topic of interest of the review, usually a theme that motivates the development of the study and is related to clinical practice. The definition of the guiding question is essential and permits the determination of the research problem, the target population, as well as the key variables. ${ }^{2}$ In addition, the review question will be the framework to determine the selection criteria of the primary studies.

The question is also relevant for the identification of the descriptors for the search of the primary studies, and, therefore, for the construction of the search strategy. The proper definition of the question is fundamental to avoid identifying irrelevant studies in view of the review purpose. To develop the IR, the suggested format for the guiding question involves the definition of the population, the intervention or condition or problem or phenomenon and the results of interest. It may also include the type of study (research design) or other criteria such as language, geographical location or time period. ${ }^{6}$

Thus, the use of the PICO format (an acronym for patient, intervention, comparison, outcomes) can help in the proper construction of the review question, ${ }^{7}$ however, it is emphasized that in IR, it is not always possible to delimit all the elements of the PICO strategy. This strategy can also be used in the PICOT format, where T stands for time, or PICOS, where S is the type of study.

Currently, most databases have interfaces to include the elements of the PICO strategy, enabling the reviewer to implement practically the same format in all selected databases. ${ }^{8}$ The elements of the strategy mentioned to formulate the review question, the definition of each element and the possible questions are described below: P) Problem, patient, population - What will be the group of interest? I) Intervention, exposition or topic of interest - Which intervention or topic will be studied? C) Comparison - Is there any comparison of the intervention? O) Outcome or results - What will be the effect of the intervention?; T) or S) Time or type of study - Will there be any restrictions regarding the publication period of the studies or type of research design? ${ }^{9-10}$

After constructing the question, the reviewer will start delimiting the controlled descriptors according to each selected database (baseline vocabulary) and keywords. The controlled descriptors and keywords should be combined according to each element of the elaborated PICO strategy, based on a logical structure, which will be the basis of the primary study search strategy.

The difference between the use of controlled descriptors and keywords is highlighted. The keywords are random and extracted from free language texts, that is, they are not structured. Controlled descriptors are organized into hierarchical structures, facilitating the search and identification of studies of interest to the reviewer. ${ }^{11}$ Structured vocabularies (controlled descriptors) allow the researcher to identify the information with the exact term, providing objective results. ${ }^{12}$ For the database (PubMed) National Library of Medicine National Institutes of Health, the terms are identified in the Medical Subject Headings (MeSH), in the Cumulative Index to Nursing and Allied Health Literature (CINAHL), in the Headings and in the Latin American and Caribbean Health Sciences Literature (LILACS) through the Descriptors in Health Sciences (DeCS), among other vocabularies.

In the identification of the controlled descriptors in the databases selected to conduct the review, the researcher may also find synonyms relevant to the term of interest. As an example, when searching for the descriptor "Cuidados de Enfermagem", the synonyms "Assistência de Enfermagem" and "Atendimento de Enfermagem" can be identified within DeCS. In this example, the search strategy for primary studies in the LILACS database could be constructed as follows: Cuidados de Enfermagem OR Assistência de Enfermagem OR Atendimento de Enfermagem.

Among the sources of access to the scientific literature, the databases and electronic libraries are highlighted. The choice of the databases will depend on the review question. ${ }^{13}$ In Brazilian nursing, the most used databases to search for primary studies are PubMed, CINAHL, 
Institute for Scientific Information Web of Science and LILACS. Among the electronic libraries, the following stand out: Scientific Electronic Library Online (SciELO), Capes / MEC Journals Portal and Science Direct. There is also the "gray literature", understood as non-impact texts that are not formally published in sources such as scientific books or journals, such as abstracts published in annals of scientific events, government reports, laws, decrees, theses, dissertations and articles published in non-indexed journals. ${ }^{13-14}$

The search strategy is defined as the technique or set of rules that makes it possible to identify the publications stored in a given database, which can answer the review question. In order to answer the guiding question, it is necessary to perform "tactical operations" to identify valid and relevant information for the purpose of the review. Undoubtedly, the preparation of the strategy, as well as the selection of the databases to be consulted, requires specialized personal and intellectual knowledge from the reviewer, such as languages, database vocabularies, Boolean logic, logical reasoning, selfconfidence, among others. ${ }^{15-16}$

A priori, there are three steps in the process of planning the search strategy: 1) decision regarding the database; 2 ) selection of search terms and their suitability in each database; 3) logical formulation of the strategy. The search strategy should be sensible and replicable. ${ }^{13,15}$

In IR, the search for primary studies should be extensive enough to ensure the identification of relevant and necessary surveys to answer the guiding question. There needs to be a balance between the search for comprehensiveness and the maintenance of relevance in its development though, in order to enable its management.

The structure of the search strategy should include a range of terms (controlled descriptors and keywords) for each element of the PICO strategy. This construct implies the use of database vocabulary terms, text words, synonyms and related terms for each concept, joining each term within each concept using Boolean operators. ${ }^{14}$ The terms employed can be combined using (AND, OR or NOT) to compose the search strategy. ${ }^{13}$ The "NOT" operator, as far as possible, should be avoided to reduce the risk of inadvertently removing relevant studies from the search. ${ }^{14}$

Among the different terms, "AND" is usually used to identify studies on two themes (intersection). Among the synonyms, "OR" is used in order to locate indexed searches with terms different from the base vocabulary. The "NOT" operator is used to exclude a specific subject from the search. In IR studies, adopting limits or restricting characteristics such as language, date or country of publication should be avoided in the search strategy, as it may represent the loss of potentially relevant studies. ${ }^{13}$

Other search techniques include the use of parentheses (used to establish order in the search process and separate the sets of terms), truncation (a method that uses the dollar sign (\$) at the end of a word), employed in the search for word roots; and quotes, used in case of compound terms. Professional librarian assistance is recommended if the reviewer does not have the necessary resources to implement the search for primary studies in the literature. ${ }^{13,15}$

\section{MANAGEMENT OF PRIMARY STUDY SEARCH RESULTS}

The use of bibliographic reference management software was initially proposed for systematic reviews (SR) studies, with the first publications on the use of this system dating back to the 1990s. ${ }^{17-18}$ Many reviewers use Microsoft Excel spreadsheets, while others select studies manually, with the printing of titles and abstracts, which makes the process complex, not ecological and time-consuming. Currently, the workflow in the review process is more streamlined with the use of computer programs. ${ }^{19}$ In a study published in 2013, the authors pointed out that more than half of the systematic reviews used the software EndNote ${ }^{\circledR} .{ }^{20}$ As the SR are similar to the IR, the use of this technology is proposed in order to facilitate the selection process of the primary studies. 
The use of bibliographic reference management programs (e.g. EndNote ${ }^{\circledR}$, Mendeley ${ }^{\circledR}$ and Zotero ${ }^{\circledR}$ ) is important to operationalize the selection of primary studies in IR. ${ }^{13}$ These programs make it possible to locate repeated references, identify languages, select publication periods, create groups according to the selection criteria (inclusion and exclusion), compare the selected references among the reviewers, as well as to create quotations while writing the scientific text, making it easier to format the references at the end of each manuscript preparation process. The choice of the software is influenced by its availability (free or paid) and by the reviewer's adaptation to the available options. In the literature, there are studies in which the authors compared the different programs. ${ }^{21-22}$ In general, the reference managers perform basic functions of locating publications, storing the results and citing references when writing the manuscript.

The selection of the program should meet the individual needs of the reviewer though, as each tool comes with advantages and disadvantages. ${ }^{21-22}$ For example, the easy use of Mendeley ${ }^{\circledR}$ is one of its strengths. On the other hand, this manager has the weakness of not allowing searches in databases within its own structure, nor does it permit dynamic changes in the formatting of citations in the texts. ${ }^{22}$ Thus, it is necessary to know each software to identify the one that best adapts to each reviewer, which is why it is worth mentioning the use of EndNote ${ }^{\circledR}$, which the authors of this article have used for more than 15 years.

In this reflection, we will discuss the use of the software EndNote ${ }^{\circledR}$, version XV. It should be noted that there is the free online version (EndNote ${ }^{\circledR}$ Basic) available on the Thomson Reuters website (www.endnote.com), which does not have all the features available in the paid version.

When creating the file in EndNote ${ }^{\circledR}$, one can also outline different groups in order to organize the search. After the search of the primary studies in the databases, in which the reviewer crossed the controlled descriptors and keywords from the PICO strategy, one can easily export the search in a file and import through the use of filters for EndNote ${ }^{\circledR}$. For example, searching the PubMed database requires the selection of the "PubMed (NLM)" filter; in the LILACS database, the filter of choice is the "Reference Manager (RIS)". Other databases, such as CINAHL and Web of Science, permit the direct import of references by double-clicking the file exported from the database. EndNote ${ }^{\circledR}$ gives its users a YouTube channel with different videos that teach how to use this software (https://www. youtube.com/user/EndNoteTraining). In addition, free, user-friendly guides are available to the users.

After importing the search in EndNote ${ }^{\circledR}$ and directing the records referring to the group that indicates each database, it is recommended to save the back-up file with the original search, without managing the content, for the purpose of retrieving publications that may have been inadvertently excluded by the user, besides having the record of the number of references identified in each database.

Another feature is to change (or customize) the available fields within the EndNote ${ }^{\circledR}$ library to identify the source of each search. The user needs to select "Tools", click "Change and Move Fields", select a field, for example "URL", select "Replace whole field with", in the right frame, enter the name of the database that group of exported references refers to and click "OK". This action changes the entire contents of the references column for the group. When executing this change in each database, the reviewer will have the exact record of the source of each reference. This should be one of the first steps taken by the reviewer. The step-by-step for the described feature and other important commands for performing review methods is available on the YouTube channel "EndNote for Systematic Reviews".

Figure 2 presents an example of the creation of groups within the reference database in the development of review methods. To do this, just right-click within "My Groups", where you can create group sets (“Create Group Set”), with new groups within each larger group (“Create Group”). These

\footnotetext{
* Available from: <https://www.youtube.com/watch?v=QHXWaAZZBqE\&list=PLF2KCgTC6mbTI5ngY2sxcKkeJ8iRCaJh7>
} 
actions permit the creation of different filtrations from the set of identified primary studies. To add references in each group, simply select the publication and drag it to the required group.

Figure 2 - Examples of groups that can be created in the selection of primary studies for integrative review, Ribeirão Preto, São Paulo, 2017

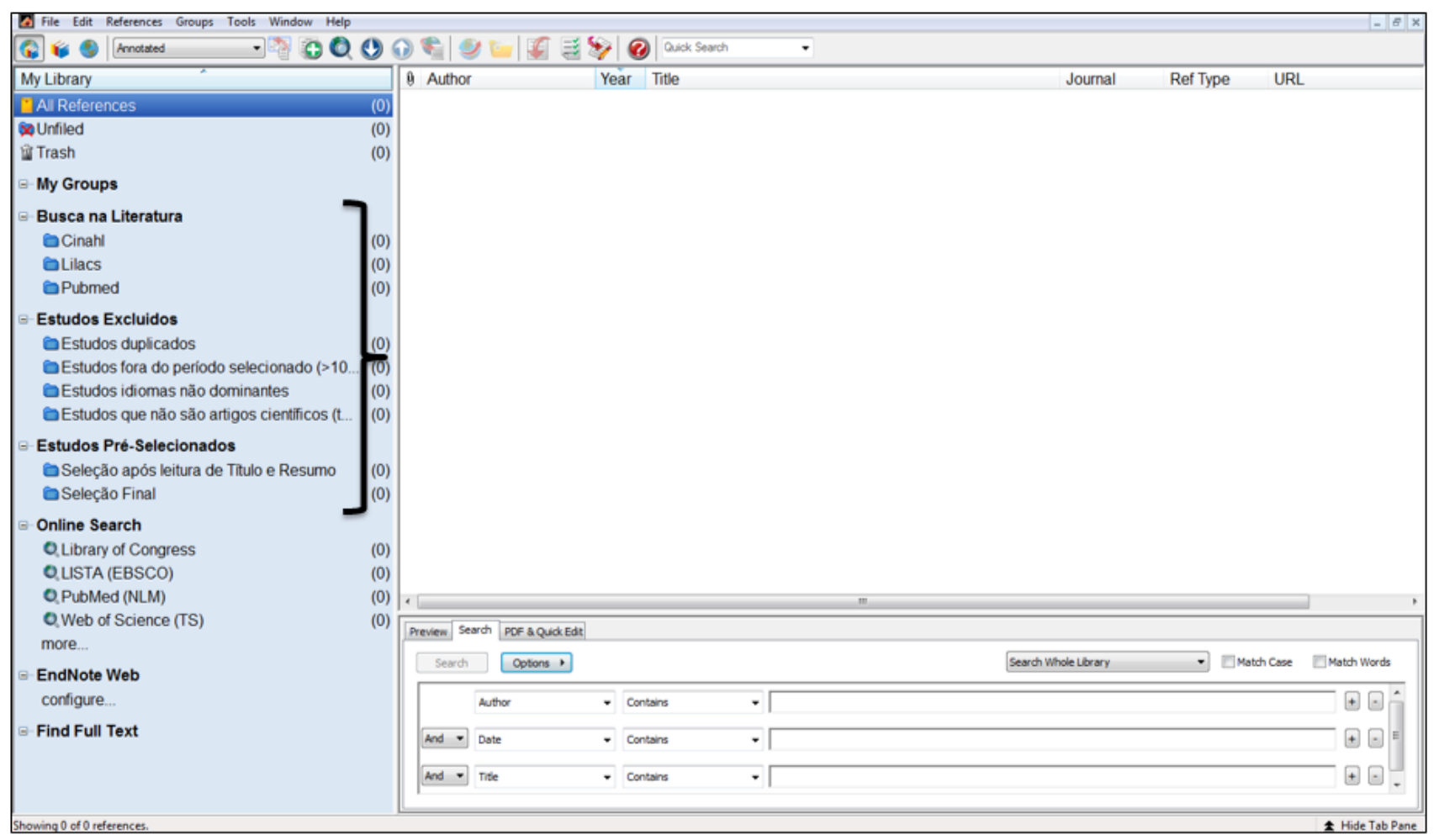

The use of EndNote ${ }^{\circledR}$ also permits changing fields within the reference base, in order to manage the inclusion and exclusion criteria independent reviewers performed. In this case, each reference receives a label, with one or more codes, justifying each reviewer's inclusion or exclusion of the primary study. In the literature, in a published study, the authors elaborated a guide on how to use EndNote ${ }^{\circledR}$ functions to enable the selection of primary studies in a rigorous and organized way. ${ }^{23}$

In the selection of the primary studies, references should be repeated (duplication of studies) in the searches performed in the different databases. Before removing duplicate studies, one needs to rename the "URL" column, indicating the database from the reference, as mentioned earlier. As shown in Figure 3, you can create a group called "Duplicate Studies" and direct all repeated references to this folder.

To select duplicate studies, the reviewer should click on the top tab named "References" and select "Find Duplicates". Through this action, the program highlights the duplicate references. The next step is to delete these references, an action that sends the duplicate texts to the "Unfiled" folder. If the program sends the duplicate references to the software's trash, you need to select these records again, right-click and select "Restore to Library". This action directs the recovered references to the "Unfiled" folder, where it can be added to the folder of interest as already mentioned. Relevant step is to select all the texts forwarded to the "Unfield" folder, right-click, and add these references ("Add References To") to the folder that will contain the duplicate studies. It is possible that, if this action is taken, some duplicate study still remains, as the reference has been extracted from different bases and is not always indexed identically. 
Figure 3 - Demonstration of export phases to the software EndNote ${ }^{\circledR}$,

Ribeirão Preto, São Paulo, 2017
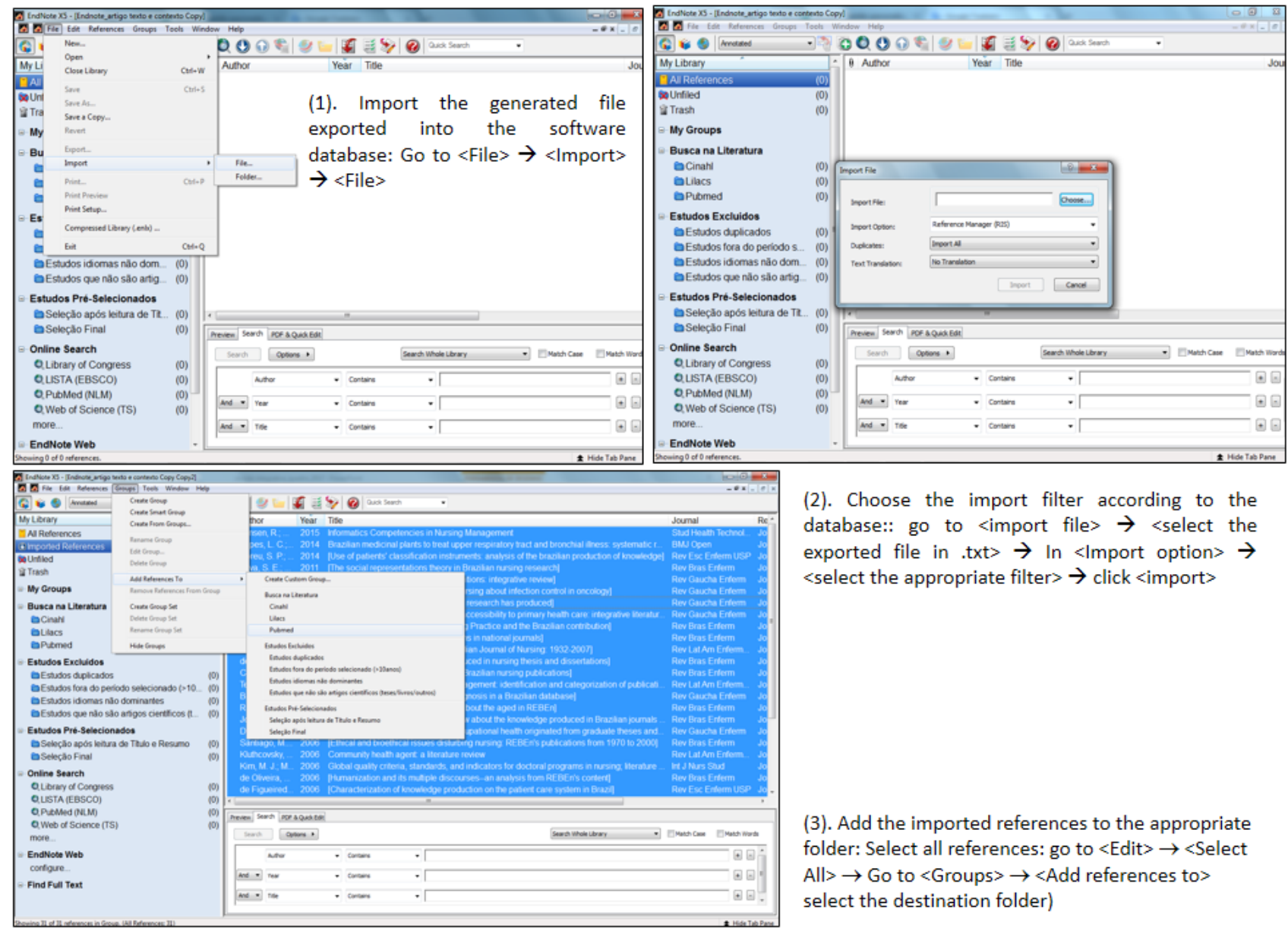

(2). Choose the import filter according to the database:: go to <import file> $\rightarrow$ <select the exported file in .txt $>\rightarrow$ In $<$ Import option $>\rightarrow$ <select the appropriate filter $>\rightarrow$ click <import>

For the selection of the year of publication, for example, the last five or ten years, the reviewer should click on the "Year" column, which appears as the heading immediately before the references. By clicking on this column, the program sorts the references according to the year of publication in ascending and descending order. The reviewer can select the references of the years of interest and do the same action previously described, that is, delete the references that are not part of the delimited period, sending them to the folder "Unfiled". Next, the reviewer should select all the texts forwarded to this folder, right-click, and add these references ("Add References To") to the folder that will contain the studies published in a period not selected to compose the sample of the review.

Two ways exist for the purpose of language identification. The first is to search within the reference database. The reviewer should note that, when clicking any folder of the groups created, different fields can be searched using the "Search" tool. When clicking on the existing options for the search, the reviewer should select the "Language" field. After this action, enter the languages the reviewer does not master or is not interested in. Depending on the database the study was extracted from, the language may be described in detail or identified by the initial three letters, for example "eng" to identify English. It may also be blank, that is, it does not contain information about the language of the reference.

The second way is to use the same "Search" tool, select the "Title" field in the search options and type the bracket symbol "[" because, most of the time, references that are in a language other than English have their titles in English in brackets. After this action, the reviewer should delete those references by submitting the articles to the "Unfiled" folder. Then select all the texts forwarded to 
this folder, right-click, and add these references ("Add References To") to the folder that will contain references published in other languages that will not be part of the review sample.

For the identification of texts that are not scientific articles, the reviewer should click on the "Ref Type" column, which appears as a heading immediately before the studies listed in the reference database. By clicking on this column, the program orders the references according to their type, making it easy, for example, to identify theses and book chapters.

Another useful feature of the program is the publication summary, an important aspect for the selection of the primary studies that will be included in the IR, by reading the title and summary of each reference. Thus, when clicking on the folder of interest, in the same place where the search takes place within the references themselves, there is an icon called "Preview", which permits the complete visualization of the reference and the abstract. Note that, for this view, in the upper tab, where it is possible to select the reference style, "Annotated" should be clicked, otherwise the user will see the last reference style used for formatting references.

To complete the advantages of using EndNote ${ }^{\circledR}$, the program also contains a full text search tool. To do this, the reviewer should select the references, right-click, and select "Find Full Text". It should be noted that the program searches for groups of 250 references, so that the reviewer should pay attention to this when searching for texts in Portable Document Format (PDF). This functionality of the program is also conditioned to the computer's IP, retrieving a larger number of texts in the institutions affiliated with the research portals, or when remote access is possible beyond the academic environment through the Virtual Private Network (VPN) service.

\section{EXAMPLE QUESTION AND SEARCH STRATEGY}

In the attempt to provide the reader with an understanding of the content addressed in the previous items, an example was elaborated, which considers the review question and the search strategies of the primary studies.

The guiding question outlined for the elaboration of IR was: "What evidence is available in the literature about the publication of integrative review studies by nurses in the Brazilian context?" Thus, the elements of the PICO strategy for the review question would be as follows: P) Nurses; I) Integrative review studies; C) Does not apply; and O) Number of studies published in Brazil.

The literature search of the primary studies was carried out via the Internet, in the following databases: PubMed, CINAHL and LILACS. To ensure a broad and careful search, the controlled descriptors and keywords were delimited in the Thesaurus according to each database, i.e. Medical Subject Headings, CINAHL Headings and Descriptors in Health Sciences. Next, the search strategies applied in each database are presented (chart 1).

For each search in the databases, an export file to EndNote ${ }^{\circledR}$ was produced, containing all the references identified after crossing the elements Problem/Participants (P) AND Intervention/Aspect of interest (I) AND Outcome/Results (O) (figures 3 and 4). 
Chart 1 - Search strategies in the databases PubMed, CINAHL and LILACS,

Ribeirão Preto, São Paulo, 2017

\section{Database Search strategy}

"Nursing"[Mesh] OR Nursings AND "Review Literature as Topic"[Mesh] OR State-

PubMed of-the-Art Review OR Review, State-of-the-Art OR Reviews, State-of-the-Art OR State of the Art Review OR State-of-the-Art Reviews OR State of the Art Reviews

OR Integrative Review AND "Publications"[Mesh] AND "Brazil"[Mesh]

CINAHL

Nurses* OR Nursing Assistants OR Registered Nurses AND Literature Review*AND Serial Publications* AND Brazil*

Nurses OR Enfermeros OR Enfermeiras* e Enfermeiros OR Enfermeira OR Enfermeira e Enfermeiro OR Enfermeiras OR Enfermeiro e Enfermeira OR Enfermeiros e Enfermeiras AND Review Literature as Topic OR Literatura de Revisión como

LILACS Asunto OR Literatura de Revisão como Assunto* OR Revisão do Estado da Arte OR Revisões do Estado da Arte AND Publications OR Publicaciones OR Publicações* AND Brazil OR Brasil OR Brasil ${ }^{*}$

${ }^{*}$ Refers to the set of controlled descriptors in English, Spanish and Portuguese

Figure 4 - Final display of searches exported to the software EndNote ${ }^{\circledR}$, Ribeirão Preto, São Paulo, 2017

\begin{tabular}{|c|c|c|c|c|c|c|c|}
\hline D) File Edin References Groups Tools Window Help & & & & & & & \\
\hline 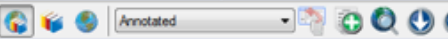 & (1) 슬 & $\because 18$ & avick Search & & & & \\
\hline My Library & 8 Author & Year & Title & Journal & Ref Type & URL & \\
\hline R All References & Storch Borges, Elsie; ... & 2016 & Relevant actions in the control of surgical site infections in... & Online Braz... & Journal Arti... & Cinahl & \\
\hline Unfiled & Rohr, Roseane Varga... & 2016 & Intervençб̃es de enfermagem com música: revisão integr... & Rev. pesqui... & Journal Arti... & LILACS & \\
\hline Trash & Rohr, Roseane Varga... & 2016 & Intervenções de enfermagem com música: revisăo integr... & Rev. pesqui... & Journal Arti... & LLACS & \\
\hline Urasn & Lessa, Quezia Cristin. & 2016 & Açōes de enfermagem ao paciente com insuficiência car. & Rev. pesqui... & Journal Arti... & LILACS & \\
\hline My Groups & Chicharo, Sandra Co... & 2016 & Fatores facilitadores do ensino-aprendizagem na formaç... & Rev. pesqui... & Journal Arti... & LLACS & \\
\hline Busca na Literatura & Budó, Maria de Lourd.. & 2016 & Cuidado e cultura: uma interface na produção do conheci... & Rev. pesqui... & Journal Arti... & LLACS & \\
\hline Cinahl & Budó, Maria de Lourd... & 2016 & Cuidado e cultura: uma interface na produção do conheci... & Rev pesqui... & Journal Arti... & LLACS & \\
\hline GLilacs & Schipper, Elles; Mahd... & 2015 & Towards an ICF core set for ADHD: a worldwide expert su... & European ... & Journal Arti... & Cinahl & \\
\hline GPubmed & Jensen, R; Casteli, C... & 2015 & Informatics Competencies in Nursing Management & Stud Health... & Journal Arti... & PUBMED & \\
\hline Fetudos Excluido & Cardoso Duarte, Mai... & 2015 & Gender and violence against women in nursing literature: .... & Rev Bras E... & Journal Arti... & Cinahl & \\
\hline Estudas Exciuias & Lopes, L. C.; Silva, M.... & 2014 & Brazilian medicinal plants to treat upper respiratory tract a... & BMJ Open & Journal Arti... & PUBMED & \\
\hline DEstudos duplicados & Froggatt, Katherine; $\mathrm{P}$... & 2014 & Guest Editorial: Development of palliative care in long ter... & Internationa... & Joumal Arti... & Cinahl & \\
\hline DEstudos fora do periodo selecionado (>1... (34) & Abreu, S. P.; Pompeo... & 2014 & [Use of patients' classification instruments: analysis of the .... & RevEsc En... & Journal Arti... & PUBMED & \\
\hline Estudos idiomas não dominantes & Yarcheski, Adela; Mah... & 2013 & Characteristics of Quantitative Nursing Research from $19 . .$. & Journal of $\mathrm{N}$... & Journal Arti... & Cinahl & \\
\hline - Estudos que não são artigos cientificos (t... (1) & $\begin{array}{l}\text { Salvador, Petala Iuan... } \\
\text { Rocha, Elyrose Sous... }\end{array}$ & $\begin{array}{l}2013 \\
2013\end{array}$ & $\begin{array}{l}\text { Participaçáa do técnico de enfermagem na sistematizaç... } \\
\text { Gestão da qualidade na enfermagem brasileira: revisão }\end{array}$ & $\begin{array}{l}\text { Rev. enferm... } \\
\text { Rev. enferm... }\end{array}$ & $\begin{array}{l}\text { Journal Art... } \\
\text { Journal Arti... }\end{array}$ & $\begin{array}{l}\text { ULACS } \\
\text { UILACS }\end{array}$ & \\
\hline Estudos Pré-Selecionados & & 2013 & Bibliography & Progress in... & Journal Arti... & Cinahl & \\
\hline ESeleção após leitura de Titulo e Resumo & & 2013 & & Consulta d... & Thesis & ULACS & \\
\hline GSeleção Final & Silva, Lolita Dopico d... & 2012 & Revisão integrativa da produção cientfica de enfermeiro... & Rev enferm... & Journal Arti... & LILACS & \\
\hline & Laurena Moreira, Pire... & 2012 & Nursing in the context of schoolchildren $L T<G T>G T<G T>>$.... & Revista Enf... & Journal Arti... & Cinahl & \\
\hline Online Search & Cipriano, Maria Aneu... & 2012 & Revisäo integrativa de estudos sobre açōes educativas p... & Rev enferm... & Journal Arti... & LILACS & \\
\hline Q. Library of Congress & & 2012 & Bibliography & Progress in... & Journal Arti... & Cinahl & \\
\hline Q.LSTA (EBSCO) & Silva, S. E.; Camargo... & 2011 & [The social representations theory in Brazilian nursing res... & Rev Bras E... & Journal Arti... & PUBMED & \\
\hline Q. PubMed (NLM) & 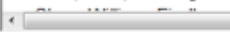 & & I"' & 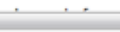 & 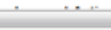 & & \\
\hline Q. Web of Science (TS) & \begin{tabular}{|l|l|l|} 
Prevew & Search & POF a Qudk Edt
\end{tabular} & & & & & & \\
\hline $\begin{array}{l}\text { more.. } \\
\text { condigure... } \\
\text { Find Full Text }\end{array}$ & \begin{tabular}{|l} 
Lessa, Q. C. d. S. S., G. d \\
Intervenciones de enfermer \\
$4587-4600$. \\
to identify studies on \\
highlight methods, \\
three databases, Lil \\
the prevalence of re: \\
consultation, the use \\
management startin
\end{tabular} & $\begin{array}{l}\text { C. Quell } \\
\text { ia para } \\
\text { educat } \\
\text { trategies } \\
\text { acs, Me } \\
\text { search o } \\
\text { of mea } \\
\text { gas ear }\end{array}$ & $\begin{array}{l}\text { Uci, et al. (2016). "Açסes de enfermagem ao paciente com in } \\
\text { pacientes con insuficiencia cardiaca: una revisión integrador } \\
\text { tional activities for patients with heart failure performed by nur } \\
\text { s and new concepts in the area. Method: this is an integrative } \\
\text { dline and Capes Journals Portal, published between } 1995 \text { an } \\
\text { on the benefits of health education provided in various perform } \\
\text { ins of distance communication and other means. Conclusion: } \\
\text { rly as possible, in hospitals and extended after discharge, obs }\end{array}$ & $\begin{array}{l}\text { Isuficiência car } \\
\text { a^ies." Rev. pe } \\
\text { ses and evaluat } \\
\text { literature revie } \\
\text { d } 2010 \text {. Result: } \\
\text { nance scenario } \\
\text { the education p } \\
\text { serving the incr }\end{array}$ & $\begin{array}{l}\text { liaca: uma re } \\
\text { qui. cuid. fun } \\
\text { e their impor } \\
\text {, with } 15 \text { arti } \\
\text { in the analy } \\
\text {, especially } \\
\text { actice shoul } \\
\text { ase of knowl }\end{array}$ & $\begin{array}{l}\text { ân integrativa ipt } \\
\text { m. (Online) } 8(2) \text { : } \\
\text { ce, in order to } \\
\text { s selected in the } \\
\text { it was observed } \\
\text { ing the nursing } \\
\text { e part of daily } \\
\text { ge of the disease }\end{array}$ & \\
\hline Showing 81 of 81 references. & & & & & & \pm Hide Tab & Pane \\
\hline
\end{tabular}

\section{CONCLUSION}

The development of IR with methodological rigor produces the synthesis of knowledge on the reviewer's topic of interest, who can contribute with recommendations based on research results for clinical practice, as well as in the identification of knowledge gaps, driving future research development. The advancement of technologies, especially bibliographic reference management software such as EndNote $\AA$, has provided resources for the feasibility of knowledge synthesis methods, with transparency and replicability, consequently improving the quality of this type of study. 


\section{REFERENCES}

1. Mallidou A. Mapping the landscape of knowledge synthesis. Nurs Manag [Internet]. 2014 [cited 2017 Oct 11];21(5):30-9. Available from: https://doi.org/10.7748/nm.21.5.30.e1242

2. Whittemore $R$, Chao A, Jang M, Minges KE, Park C. Methods for knowledge synthesis: an overview. Heart Lung [Internet]. 2014 [cited 2017 Oct 11] ;43(5):453-61. Available from: https:// doi.org/10.1016/j.hrtlng.2014.05.014

3. Galvão CM, Sawada NO, Rossi LA. Evidence based practice: theoretical considerations for its implementation in perioperative nursing. Rev Latino-am Enfermagem [Internet]. 2002 [cited 2017 Oct 11];10(5):690-5. Available from: http://www.scielo.br/pdf/rlae/v10n5/v10n5a10.pdf

4. Galvão CM, Mendes KDS, Silveira RCCP. Revisão integrativa: método de revisão para sintetizar as evidências disponíveis na literatura. In: Brevidelli MM, Sertório SCM, eds. Trabalho de conclusão de curso: guia prático para docentes e alunos da área da saúde. São Paulo: látria; 2010:105-126.

5. Mendes KDS, Silveira RCCP, Galvão CM. Revisão integrativa: método de pesquisa para a incorporação de evidências na saúde e na enfermagem. Texto Contexto Enferm [Internet]. 2008 https://doi.org/10.1590/S0104-07072008000400018

6. Ho GJ, Liew SM, Ng CJ, Hisham Shunmugam R, Glasziou P. Development of a search strategy for an evidence based retrieval service. PloS One [Internet]. 2016 [cited 2017 Oct 11];11(12):e0167170. Available from: https://doi.org/10.1371/journal.pone.0167170

7. Hastings C, Fisher CA. Searching for proof: creating and using an actionable PICO question. Nurs Manage [Internet]. 2014 https://doi.org/10.1097/01.NUMA.0000452006.79838.67

8. Cooke A, Smith D, Booth A. Beyond PICO: the SPIDER tool for qualitative evidence synthesis. Qual Health Res [Internet]. 2012 [cited 2017 Oct 11];22(10):1435-43. Available from: https://doi. org/10.1177/1049732312452938

9. Methley AM, Campbell S, Chew-Graham C, McNally R, Cheraghi-Sohi S. PICO, PICOS and SPIDER: a comparison study of specificity and sensitivity in three search tools for qualitative systematic reviews. BMC Health Serv Res [Internet]. 2014 [cited 2017 Oct 11];14:579. Available from: https://doi.org/10.1186/s12913-014-0579-0

10. Galvão TF, Pereira MG. Revisões sistemáticas da literatura: passos para sua elaboração. Epidemiol Serv Saúde [Internet]. 2014 [cited 2017 Oct 11];23:183-4. Available from: https://doi.org/10.5123/ S1679-49742014000100018

11. Hanauer DA, Mei Q, Law J, Khanna R, Zheng K. Supporting information retrieval from electronic health records: A report of University of Michigan's nine-year experience in developing and using the Electronic Medical Record Search Engine (EMERSE). J Biomed Inform [Internet]. 2015 [cited 2017 Oct 11];55:290-300. Available from: https://www.ncbi.nlm.nih.gov/pmc/articles/PMC4527540/ pdf/nihms695773.pdf

12. Grant MJ. Key words and their role in information retrieval. Health Info Libr J. 2010 [cited 2017 Oct 11];27(3):173-5. Available from: https://doi.org/10.1111/j.1471-1842.2010.00904.x

13. Pereira MG, Galvão TF. Etapas de busca e seleção de artigos em revisões sistemáticas da literatura. Epidemiol Serv Saúde [Internet]. 2014 [cited 2017 Oct 11];23:369-71. Available from: https://doi.org/10.5123/S1679-49742014000200019

14. Lefebvre C, Glanville J, Wieland LS, Coles B, Weightman AL. Methodological developments in searching for studies for systematic reviews: past, present and future? Syst Rev [Internet]. 2013 [cited 2017 Oct 11];2:78. Available from: https://doi.org/10.1186/2046-4053-2-78

15. Koopman B, Bruza P, Sitbon L, Lawley M. Towards semantic search and inference in electronic medical records: An approach using concept-based information retrieval. Australas Med J [Internet]. 
2012 [cited 2017 Oct 11];5(9):482-8. Available from: https://www.ncbi.nlm.nih.gov/pmc/articles/ PMC3477777/pdf/AMJ-05-482.pdf

16. Uzuner $O$, Stubbs A. Practical applications for natural language processing in clinical research: The $2014 \mathrm{i} 2 \mathrm{~b} 2 / \mathrm{UTHealth}$ shared tasks. J Biomed Inform [Internet]. 2015 [cited 2017 Oct 11]; 58(Suppl):S1-5. Available from: http://ac.els-cdn.com/S1532046415002294/1-s2.0-S1532046415002294-main. pdf?_tid=e123f084-1bb3-11e7-acc0-00000aab0f26\&acdnat=1491584684_5dc360eccc9995ae5 34eb458488af0a4

17. Miller MC. Reference management software: a review of EndNote Plus, Reference Manager, and Pro-Cite. MD Comput. 1994;11(3):161-168.

18. Sato H, Sato S, Horikoshi I. Implementation of a reference management system, MacRefer, under HyperCard. Comput Meth Prog Bio [Internet]. 1996 [cited 2017 Oct 11];50(1):53-61. Available from: http://ac.els-cdn.com/0169260796017312/1-s2.0-0169260796017312-main.pdf?_tid=6d5fcac81bb4-11e7-b502-00000aab0f01\&acdnat=1491584920_80f11a7045e15544c5b974213ef108c4

19. Bramer WM, Milic J, Mast F. Reviewing retrieved references for inclusion in systematic reviews using EndNote. J Med Libr Assoc [Internet]. 2017 [cited 2017 Oct 11];105(1):84-7. Available from: https://www.ncbi.nlm.nih.gov/pmc/articles/PMC5234463/pdf/jmla-105-84.pdf

20. Lorenzetti DL, Ghali WA. Reference management software for systematic reviews and metaanalyses: an exploration of usage and usability. BMC Med Res Methodol [Internet]. 2013 [cited 2017 Oct 11];13:141. Available from: https://doi.org/10.1186/1471-2288-13-141

21. Zhang Y. Comparison of select reference management tools. Med Ref Serv Q [Internet]. 2012 [cited 2017 Oct 11];31(1):45-60. Available from: https://doi.org/10.1080/02763869.2012.641841

22. Yamakawa EK, Kubota FI, Beuren FH, Scalvenzi L, Miguel PAC. Comparativo dos softwares de gerenciamento de referências bibliográficas: Mendeley, EndNote e Zotero. Transinformação [Internet]. 2014 [cited 2017 Oct 11]; 26:167-76. Available from: http://www.scielo.br/pdf/tinf/ v26n2/0103-3786-tinf-26-02-00167.pdf

23. King R, Hooper B, Wood W. Using bibliographic software to appraise and code data in educational systematic review research. Med Teach [Internet]. 2011 [cited 2017 Oct 11];33(9):719-23. Available from: https://doi.org/10.3109/0142159X.2011.558138 


\section{NOTES}

\section{CONTRIBUTION OF AUTHORITY}

Study design: Mendes KDS.

Writing and / or critical review of content: Mendes KDS, Silveira RCCS, Galvão CM.

Review and final approval of the final version: Mendes KDS, Silveira RCCS, Galvão CM.

\section{ETHICS COMMITTEE IN RESEARCH}

Not applicable.

\section{CONFLICT OF INTEREST}

No any conflict of interest.

\section{CONSENT OF USE OF IMAGE}

Not applicable.

\section{HISTORICAL}

Received: April 17, 2017.

Approved: November 8, 2017.

\section{CORRESPONDENCE AUTHOR}

Karina Dal Sasso Mendes

E-mail: dalsasso@eerp.usp.br 